\title{
Ink on paper
}

[T] he real problem, the central mystery of politics is not sovereignty, but government ... it is not the law, but the police - that is to say, the governmental machine that they form and support.

Giorgio Agamben, The Kingdom and the Glory

The reign of an absolute monarch is something of a rarity in the modern world. Amid the pressures of modernity, the ability to lay claim to absolute power is limited to a small number of states, a number of whom are in the Middle East. Yet such absolute power is not limited to monarchies. The prevalence of authoritarian rule across the Middle East has led to the establishment of what Nazih Ayubi has termed 'fierce states', echoing Friedrich Nietzsche's definition of the state as 'the coldest monster'.

This chapter looks at the way in which a range of political structures - formal and informal - have been created in pursuit of regime survival. Although typically viewed as the security mechanisms of a state, coercive capabilities are also embedded within the regulatory mechanisms of political systems and the ability to create bare life, underpinned by claims to legitimacy. In pursuit of this, regimes embed themselves within local contexts of tribalism, history, religion and civic myths that shape politics in an attempt to survive.

The development of political communities and the systems that regulate and order them are an essential part of closing off a community against an outside. The development of political structures is an essential part of this process, restricting the capacity of action but also giving meaning. As we have seen, amid a regional environment underpinned by shared memories and norms, the spatial exception is not restricted to one territorial area; what happens in one state can have regional implications and vice versa. The residue of history, ideology and the spread of identities across the region creates conditions that facilitate mobilisation around cross-border issues, posing serious challenges to states and structures designed to regulate life. Central to our exploration of the regulation of life and of the ban that underpins such regulation is the contingency that shapes political systems. 
Acknowledgement of this position demonstrates that rulers have carefully crafted both a narrative and political infrastructure that draws upon an array of different mechanisms of control to regulate life. While religion, ideology and tribal loyalties have been moulded to meet domestic and regional needs, ruling elites have also created formal structures with the aim of ensuring the survival of the regime. Constitutions have been designed to draw upon cultural reserves to ensure that regimes are often taken to be representative of states, while opponents are often marginalised. They are imbued with a range of mechanisms to help maintain control through the capacity to strip political meaning from life, in a manifestation of the ban, and the capacity to derogate from the rule of law. Ultimately, regime survival and sovereign rule is dependent upon the combination of legitimacy, coercive capabilities, and the extent to which these aspects are embedded within territoriality.

\section{Authoritarianism and political structures}

Across the Middle East, newly established states were populated by nascent bureaucracies, with homogeneity and equality claimed to be at the heart of new political projects. ${ }^{1}$ Security (and stability) was the primary concern of colonial overlords, yet politics was seen as a prominent mechanism of divide and rule strategies, manifesting in political structures such as in Lebanon, in tribal courts of Transjordan, or administrative separation and de facto Alawi and Druze states in Syria. ${ }^{2}$ Within this, a number of forms of political systems have been employed with various social implications, from the Lebanese consociational model to the theocratic Islamic Republic of Iran. Each form of political organisation is unique and predicated upon context-specific contingent factors found in demographics, history, ideology and intended outcome, creating unique nomoi that operate within a global nomos.

While a cursory glance at the region sees elections in a number of states, amid various different contexts and to varying degrees of success, it is difficult to conclude that these projects meet the criteria to be considered democratic. Although elections for political positions have been an integral part of political life - understood in different ways with different restrictions - in Lebanon, Bahrain, Turkey, Israel, Iran and Kuwait, others had different experiences with democratic processes, amid allegations of corruption and malpractice. Elections have also taken place within more contested arenas such as the Kurds in Northern Iraq in 1992, Yemen in 1993, Iraq in 2005 and subsequent years and Egypt in 2012. Yet these electoral experiences do not prove the successful application of democracy, nor do they demonstrate its failure. While a number of democratic characteristics may be present, such as the shura meetings and tribal audiences, these have not always been replicated into the formal political structures of states, meaning authoritarian politics has dominated the region. ${ }^{3}$ With this in mind, a number of scholars have undertaken taxonomies to articulate difference within authoritarian rule, to include strength, reformist, rentierism, fragility and failure. ${ }^{4}$ 
The dominance of authoritarianism stems from a number of reasons: first, weak civil society prohibits the emergence of a strong democratic culture, while the legacy of unions and associations have fuelled the strength of networks of patronage that cut across the region. Second, economies have historically been state run. Although in recent years a number of states have embraced liberalisation and market forces (such as Israel and the Gulf states), the legacy of statist ideologies and the power of rentierism has placed regimes centrally within the state and once again, constrained the power of society. Moreover, it has facilitated the spread of corruption through networks of patronage, where the ultimate goal was mobilising popular support, retaining authority and autonomy, but to prevent the emergence of the organised masses. ${ }^{5}$ The potential implications of such issues are explored in depth by Hannah Arendt in The Origins of Totalitarianism, where she argues that the power of the mob has the capacity to dramatically reorder political characteristics of society, demonstrating the power of normative structures to reshape political life. ${ }^{6}$

Third, levels of education have historically been low, amid large-scale inequality. Although a recent youth bulge has co-incided with improved literacy rates and the number of people graduating with degrees, many find that there are few employment opportunities. Fourth, the region was largely absent from the third wave of democratisation that spread across the world, which Eva Bellin suggests is a consequence of geographic remoteness from the epicentre of democratisation. ${ }^{7}$ Of course, the distinctive experiences of states across the region have created unique forms of authoritarian rule and, in the cases of Israel, Kuwait, Turkey and Lebanon, some form of democratic politics. Ultimately, difference shapes the nature of local nomoi, along with the intricacies of the ban.

In a number of cases, emergency powers have transitioned from exception to norm, often becoming 'coded' within legal structures of states. In Egypt, a paradigmatic example of the seemingly permanent use of emergency laws to regulate life, consecutive regimes used the law as a means of controlling populations. For the thirty years prior to the uprisings of 2011, the state existed under a de facto and de jure state of emergency, restricting civil liberties and political participation through the expansion of security organs of the state and blurring the legal and illegal. ${ }^{8}$ The roots of such a strategy are found in the British military presence in the country, where Martial Law 15/1922 was used in 1914 as a mechanism of control but it was under Nasser when the blurring of law and politics, legal and illegal, became the norm. After Nasser, consecutive Egyptian presidents used emergency powers to maintain sovereign rule, embedding the exception within the fabric of the Egyptian state. ${ }^{9}$ Similar experiences are found in Syria and Israel, where the perennial use of emergency powers creates the possibility to create bare life.

Beyond emergency powers, political systems can serve as a mechanism of overcoming societal differences through the cultivation of consociational systems of government, power-sharing agreements that give a political voice to elite representatives from societies beset by communal divisions. In Lebanon, the Taif Accords that ended a fifteen-year long civil war established a power-sharing system of government that embedded communal identities within the fabric of the political system. As Arend Lijphart advocates, the consociational approach seeks to facilitate resolution through 
bringing elites from key segments of society together to build coalitions, transforming a zero-sum game into a spirit of cooperation and compromise and softening communal differences. ${ }^{10}$ Embedding communal difference into the political system provoked a great deal of criticism, but in recent years a number of scholars and analysts have softened their stance, suggesting that the power-sharing agreement has maintained peace, albeit within the context of a stagnating political climate and ongoing structural violence. ${ }^{11}$

We must also consider how structures have been used to integrate citizenship strip political meaning from life within the context of the camp. The reform of political structures and institutions plays a prominent role within the (re)development of the ban. The development or reform of institutions allows for the cultivation of new rules, structures and procedures, including constitutional reform, decentralisation, supervision of elections and abolition of particular ministries. ${ }^{12}$ Of course, reform can also move away from liberalisation, as domestic challenges have often resulted in deliberalising moves. A cursory glance at political systems across the Middle East reveals that reform has been a regular characteristic of political life in the previous four decades: new constitutions, reform of existing constitutions, electoral experiments and a range of other reforms have been made in an effort to ensure regime survival.

One such example is the political liberalisation that took place in Egypt under Sadat's process of infitah (openness in terms of economic liberalisation). In Jordan, the first parliamentary elections were held in 1989, while in Syria, parliament was expanded to allow independents to stand in 1990. In 1992, Saudi Arabia established its Basic Law, al hukm al-asi, to legislate for fundamental civic rights, also adding a consultative majlis ash-shura the same year. Across the Gulf, new constitutions were created in 2000, which gave women the vote in Qatar, while reform in Bahrain was part of a political package to ease transition to the rule of King Hamad in 1999.

\section{Constitutions, citizenship and 'the ban'}

Political systems and their constitutions are manifestations of the formal regulation of life, adding stability and permanence to political communities. Although executives have played a dominant role within the context of Middle Eastern politics, constitutions underpin their activity and capacity to operate in a particular way. Such manifestations occur in a range of different guises and with different priorities, from monarchies to republics. Essential to our exploration is an understanding of the issue that arises when considering the interaction of ordnung and ortung and the ensuing implications for law, politics and ultimately, sovereignty.

Territorial dimensions of legal structures are often run in contradiction with broader commitments to a non-territorial community, a theme that is covered in more detail in the following chapter. This creates a dichotomy between territorial and personal laws (and obligations), both constitutionally and in customary practice. Reference to the personal does not just evoke a sense of individualism, but also to community groups often manifesting in federalism. Thus, another way of viewing this 
tension is between communitarian and territorial federalism, wherein legal structures shape the life of community groups.

The struggle to resolve this tension while retaining legitimacy manifests in institutional building and transnational integration, impacting upon individual loyalties. ${ }^{13}$ Along with regional experiences, Islamic tradition contains within it rich sources of democracy and civil society. Fundamental to this is the idea that the Quran contains verses stressing that affairs must be resolved through shura or a process of consultation. ${ }^{14}$ Ideas of civil society are also found within classical Islam, understood as those activities taking place beyond state control including a merchant bourgeoisie, an active judiciary and the presence of scholars all acting independently of state structures. ${ }^{15}$ Islamist movements have traditionally capitalised upon access to such civil society, where groups have typically been able to exert influence. Ensuring that societies are run in accordance with norms is a concern for those seeking to derive legitimacy for their rule and to regulate life, from which the nomos offers a set of guidelines to regulate political activity; as such, a number of states have established constitutional offices to protect such norms.

It is hardly surprising that religion occupies a central role in political structures. Islam is the state religion in all but four of our states of inquiry (Israel, Turkey, Lebanon and Syria), while Islamic teachings serve as a source of law or legislation in all but three (Israel, Turkey and Lebanon). Constitutions reflect the prevalence of Islam both in the religion of the state but also through the construction of laws. In contrast, Turkey explicitly stresses its secular character. For instance, Article 2 states that, 'The Republic of Turkey is a democratic, laic and social state governed by the rule of law', while Article 174 aims to 'safeguard the laic character of the Republic'. Israel is careful to stress its democratic character, although it is also explicitly Jewish. ${ }^{16}$ In Saudi Arabia the Basic Law of Governance of 1992 provides regulatory oversight, which is underpinned by 'the Book of God and the Sunna of the Prophet.' ${ }^{17}$ Within such a context, elections were deemed inappropriate by King Fahd, the kingdom's fifth ruler. ${ }^{18}$ In addition to such laws, norms serve as a mechanism to regulate life, seen most visibly through the importance of tribalism across the kingdom. ${ }^{19}$

Political projects are comprised of peoples, both citizens and non-citizens alike. An integrated notion of citizenship is created through recourse to political and legal structures, which, in turn, are shaped by culture and the interaction of identities and ideology. For Agamben, " "the people" represents a fundamental "biopolitical fracture", ${ }^{20}$ the totality of those integrated and sovereign citizens. This too is an exclusionary concept, referring to 'a fragmentary multiplicity of needful and excluded bodies, ${ }^{21}$ or who were never included within the political project. As Michael Shapiro suggests, we should view citizenship in such a way, while also adding a temporal element into the discussion, which helps with the consistent process of 'renegotiation.' ${ }^{22}$

Citizenship occupies a central role within political projects, serving as the way in which a community closes itself off against an outside. By enshrining this difference in law, a community gains security and a temporal permanence. Yet the establishment of a number of nation states appeared at odds with traditional visions of identity, many of which transcend the sovereign state. At such points, closing the inside off against 
an outside that engenders loyalty among many of the inside appears increasingly difficult. Fundamentally a normative project that enshrines legal rights to people in their relationship with their polities, citizenship is seen by many to be an act that seeks to impose control on sovereign power. ${ }^{23}$ Conversely, as Arendt argued, citizenship rights may be revoked as a mechanism of exclusion and control. ${ }^{24}$ Historically used to regulate the bidoon ${ }^{25}$ in Kuwait and Palestinians, the denial of citizenship rights continues to be powerful tool in the arsenal of regimes. ${ }^{26}$

Establishing states requires the closing off of an inside against an outside but even this does not necessarily entail citizenship but membership, which can be revoked through recourse to bare life. The process of state building posed a number of serious challenges to the creation of a citizenship body, requiring the delineation of territory, control of borders and identification of people to populate the new project. To identify with the nation, loyalty had to transcend traditional forms of identification that were based on looser affiliations to create loyalty to the state and, perhaps more importantly, to the interests of regimes. ${ }^{27}$ Traditionally, those who can claim citizenship are able to trace their family lineage and territorial linkages through male parentage to the pre-independence eras.

Such concerns are particularly prominent in those states where the establishment of national projects challenged the pre-existing organisation of political life. Debate about the nature of citizenship has taken on political meaning, shaped by the context and contingency within which such considerations take place, and underpinned by nationality laws that establish stringent criteria defining who can - and cannot - be considered as belonging to the community and should be a citizen. ${ }^{28}$ While naturalisation clauses have been added, these are underpinned by security concerns and fears about the regime survival. ${ }^{29}$ Citizenship comes with a number of benefits. It is a mechanism to ensure loyalty amid stronger pulls towards Arab nationalism, pan-Islamism or indeed stronger nationalisms across the Gulf, facilitated by the rentier bargains that are prominent throughout the Gulf. ${ }^{30}$ Access to such resources helped to cultivate loyalty and legitimacy among peoples, increasing regime authority in the process. ${ }^{31}$

The formation of states and their citizenry has been underpinned by concerns about sedition and fear about the potential to manipulate domestic events for nefarious reasons. The process of establishing control and delineating populations was shaped by the need to not only maintain security but to carve out individual identities that differentiate new political projects from what came before and from their neighbours. ${ }^{32}$ The establishment of the United Arab Emirates out of seven distinct emirates, each with their own local identity, provides an example of such an issue. This process of establishing a federal entity posed questions about the eligibility of citizenship and passports, particularly amid the presence of a large percentage of Dubai's population who were of Persian origin. ${ }^{33}$ Perhaps the most obvious example of this - discussed in more detail below - concerns the Kuwaiti bidoon, who were marginalised as a consequence of an exclusionary vision of nationality law, but one that remains pertinent today.

One response to such concerns is the revocation of citizenship - creating conditions of bare life - and in a number of cases, rendering individuals as stateless. This process gets to 
the very heart of ideas of belonging - inclusion - within political projects but also reveals the importance of context and contingency in decisions of revocation. The removal of citizenship serves as a means of excluding people from political projects, revoking their access to the benefits of citizenship with implications for their families, particularly as most of those whose citizenship has been revoked are men and nationality is traditionally passed through the father. Ultimately, it serves as a deterrent against political protest. The nature of citizenship reveals a great deal about the process through which the ban is applied and, conversely, through which life can be stripped of its political meaning. Recourse to the ban facilitates the creation of bare life, allowing for the marginalisation of peoples through the potentiality of the exception. The revocation of citizenship serves as one of the more prominent manifestations of sovereign power in operation yet potentiality means that all people can be reduced to the figure of homo sacer.

A more obvious means of understanding exclusion is revealed through consideration of the citizen-non-citizen binary. Such an approach locates citizenship both within a clearly delineated territorial space and shared cultural community, typically associated with traditional ideas about sovereignty. This vision of citizenship suggests that in search of national identities, people buy into the production of particular narratives and historiographies which supersede other identities. This position involves the development of a national myth that seeks to create a homogenous identity, derived from shared culture and tradition. Ideas that underpin such national myths and belonging require education to evoke ideas of the 'imagined community. ${ }^{34}$ In many cases, this has taken place within communal identities rather than at the national level, although in recent years, Gulf states have developed educational curricula that stress the importance of nationalist narratives. ${ }^{35}$

Amid loyalty to a range of different identities and ideologies, the construction of identity becomes incredibly complex. While the previous chapter outlined the importance of the pan ideologies of Arabism and Islamism which leave a strong residue of community spirit and belonging within contemporary political life, ${ }^{36}$ the construction of citizenship within states often runs contrary to such sentiments. People thus retain a semblance of loyalty to both domestic and regional identities. Moreover, the formal and normative structures that emerge from history and cultural legacies typically manifest in a range of demotic experiences that are contingent upon socio-economic, cultural contexts.

Constitutions are central to these structures, which in many cases stress the importance of equality and inclusion, yet the reality of political life is somewhat different. While Article 17 of the Omani Constitution articulates that, 'All citizens are equal before the Law and share the same public rights and duties. There is no discrimination between them on the ground of gender, origin, colour, language, religion, sect, domicile, or social status', consideration of relations between indigenous Omanis and migrant workers reveals such clauses to be hollow. For those marginalised from political life, equality and inclusion are words not deeds or, as a Yemeni aphorism goes, 'ink on the paper', meaningless as few across the state care about what is written, while the central government struggles to regulate life. ${ }^{37}$ Demands for equality and greater representation have long been a prominent feature of political opposition across 
the region, yet such calls have often been ignored..$^{38}$ For others, although important, citizenship and equality mean very little when people are not treated as such, reflecting deeper existential concerns about the nature of political life. ${ }^{39}$

Political systems serve as mechanisms of control and population management, facilitating the regulation of life while also aspiring to bring people together as an inside. In Lebanon, the Taif Accords provided major sects with permanent access to decision-making, as the key portfolios of the state are distributed between Sunni, Shi'i and Maronite. Although important in creating peace, the powersharing system entrenched difference along communitarian lines, ${ }^{40}$ feeding into political stagnation and exacerbating corruption along communal lines. In spite of this criticism some acknowledged that the agreement had prevented the descent into war. ${ }^{41}$

In Iraq, an informal system of consociational governance, the Muhasasa Ta'ifa (sectarian apportionment) was established in 2003, designed to empower representatives from Sunni, Shi'a and Kurdish communities. The implementation of this system drew upon plans made by Iraqi opposition groups at a conference in 1992 which was then imported into the country along with the exiles who became the state's new 'elite'. The Muhasasa system allocated positions according to the 'Salah al-Din principles', dividing jobs along the percentage estimates of Shi'a Sunni and Kurdish groups. These identities were placed at the heart of the agreement, which brought together a range of political parties from different communities. ${ }^{42}$ As Toby Dodge has pertinently acknowledged, the Muhasasa Ta'ifa system has 'greatly weakened the Iraqi state, resulting in endemic corruption and widespread inefficiency. It also created conditions where the United States, Saudi Arabia and Iran could exploit Iraqi politics in pursuit of their own interests, seen in the role of Major General Qassem Soleimani playing a prominent role in government formation in 2006, 2010, 2014 and $2018 .{ }^{43}$

In what followed, a form of federal system was established in Iraq, creating an autonomous Kurdish zone, largely distinct from the administrative power of Baghdad, the first instance of autonomous Kurdish rule since the short lived Mahabad Republic. Of course, the implications of such structures are strongly felt in the construction of identity that replicates the community rather than the territorial. The creation of divisions - in spite of constitutional nods to inclusion - strengthen loyalty to particular identities, while conversely increasing the power of narratives of victimhood. ${ }^{44}$ Recounting the dominance of religious identities, one senior Kurdish policy advisor suggested that 'we don't have Iraqis in Iraq. ${ }^{45}$

\section{Tribes, culture and tradition}

At the heart of mass mobilisation is the power of identity and ideology. We should not view agents as the passive carriers of identity but rather as the bearers of identities, performing their roles in accordance with generally accepted practice along normative lines. Within this, identity does not operate in a primordial sense; rather, 
it is (re)constructed and negotiated across time and space, shaped by context and the contingency of daily life. Identity is performed, where actors behave in accordance with normative structures that clearly delineate the boundaries of acceptable action and the state. Such performances feed into the construction of the nomos, as each actor brings with them their own experiences and agendas that shape the regulation of political life. Within this, regimes seek to exert regulatory power and to penetrate society, but their ability to do so reveals a great deal about their own power.

The modern process of state formation was an effort to penetrate and regulate a society that was itself already regulated in accordance with previously accepted norms. New forms of political organisation contested the already existing relationship between ordnung and ortung. Different processes of tribal assimilation and contestation are seen across political projects, at various speeds and characterised by distinctive rhythms. Moreover, this did not result in the end of tribes but rather the beginning of a new set of relationships between power brokers across time and space, creating new forms and performances of regulatory power, drawing upon history, identity, solidarity and norm. ${ }^{46}$

Scholars including Albert Hourani, Philip S. Khoury and Joseph Kostiner have different understandings of the characteristics of a tribe, while the assimilation of tribal groups into political structures has itself become a site of contestation. ${ }^{47}$ Efforts to assimilate tribal structures into political organisation are shaped by local and regional context, along with the particular rhythms of tribal groups, which may fall in-between different nomoi. The process of assimilation is a central part of state-building projects.

Khaldun's work on tribes reveals a great deal about the factors that bind such groups together, based on a shared asabiyyah, the principles of military-administrative slavery and religion. While these characteristics have evolved from Khaldun's initial reflections we continue to see the importance of such ideas in the contemporary state, offering a way of regulating life within contested political organisations. ${ }^{48}$ Tribal values go alongside religion in providing a pool of reserves to legitimise political action and to help penetrate and regulate life across the modern state.

Tribal groups are malleable entities, with religious and political loyalties often transcending those of the family or the tribe. As we saw in the Battle of Jahra, members of the $\mathrm{Al} \mathrm{Ajmi} \mathrm{tribe} \mathrm{fought} \mathrm{one} \mathrm{another} \mathrm{as} \mathrm{a} \mathrm{consequence} \mathrm{of} \mathrm{different} \mathrm{political} \mathrm{loyalties.}$ In Jordan, much like in Iraq and Saudi Arabia, the key to domestic stability was to facilitate networks of patronage through tribal links, attracting tribal chiefs, co-opting their interests and consolidating influence. ${ }^{49}$

Amid this contestation and a struggle for legitimacy, regimes lay claim to whatever forms of legitimacy it may draw upon, often embodied in the ritualistic performances of tradition..$^{50}$ With such normative structures embedded within institutions and civil society, neopatrimonialism finds traction across society. As Rabi suggests, cultural heritage (turath) is a 'means to self-recognition', an expression of a fixed community in spite of diverse manifestations at an individual and collective level. ${ }^{51}$ Put another way, turath is a means of expressing solidarity with another through the acknowledgement of a shared tradition that can be expressed and performed as law, albeit perhaps also in combination with religious and state law. ${ }^{52}$ Much like identities, turath can be 
found at different groups, allowing for the cultivation of asabiyyah among different communities, including tribe, ethnicity and religion.

The importance of turath is also seen as a mechanism to construct legitimacy. Typically, this has been viewed through an analysis of the performance of institutions, but within the context of rentier politics, predicated upon a particular form of social contract that requires no taxation but provides little in the way of formal political expression, justice and turath play an important role. ${ }^{53}$ With this in mind, Rabi speaks of the revival of turath in pursuit of a particular political function (wazifa siyasiyya). Islam serves as a cultural bond to tie people together within the context of political organisation, yet this was also shaped by the colonial experience, shared linguistics and culture. Although often at odds with the state, these movements are driven by leaders seeking to improve their legitimacy reserves and ensure regime survival.

Across a range of different contexts, regimes have used networks of patronage as a means of ensuring regime survival, which have, in recent years, begun to transcend state borders. This strategy of (neo)patrimonialism builds upon - and cultivates - new links across state structures, capitalising upon shared religious, tribal or ethnic identities that can be harnessed to regulate life, but conversely as a means of challenging political order. Within this melange of identities and norms, stability is achieved if its authority pattern is congruent with other authority patterns at play in society. ${ }^{54}$

\section{Colonial legacies and regional forces}

Further stressing contingency, global context has long provided justification and support for authoritarian regimes, first in the struggle against Communism, in some instances Arab nationalism, and more recently within the context of the War on Terror. This has provided embattled regimes with valuable international support or revenue, which can prove invaluable. As Luciani suggests, even 'limited revenue from abroad dramatically improves the state's ability to buy legitimacy through allocation and increases regime stability. ${ }^{55}$ One way in which this was achieved was through the tribe, which also serves as a means of demonstrating turath and maintaining control over space. This complex web of interrelations has embedded tribal groups within the socio-economic activities of the state, as we shall see, most notably the commercial and military arms of the state. ${ }^{56}$

The establishment of the territorially grounded nation state is a consequence of the collapse of imperial states that had far looser governance structures in peripheral areas, allowing tribal leaders greater autonomy. The assimilation process thus requires bringing such groups under the control of the sovereign, along with transforming tribes into citizens while retaining their tribal history. Yet in many cases, tribes retained a prominent role within state structures through their regulatory and distribution prowess. Harnessing the power of tribal norms and culture arms regimes with legitimacy and a strong regulatory arsenal, yet the inability to do so creates uncertainty and contestation, particularly in times of crisis, as the state is largely unable to develop 
institutions that can curtail the capacity of powerful tribal groups and lineages that offer a different way of doing politics and ordering space. ${ }^{57}$

Establishing a state over lands populated by a multitude of tribes is a difficult task. After the fall of the Ottoman Empire, the failure to address the challenges of the socioeconomic landscape and the inability to assimilate rural tribal groups into the body politic of the new nation state left urban elites at the whim of powerful rural currents who were able to 'capture the state', framing its own interests and asabiyyah as the national interest. ${ }^{58} \mathrm{Of}$ course, fundamental tensions exist between states and tribes and the process of state formation sought to reconcile such differences through developing asabiyyah and coercion.

While the colonial era helped to establish political structures and institutions, it was most instrumental in defining the territorial aspects at play, as 'distinct states. ${ }^{59}$ Perhaps though, as Lisa Blaydes suggests, we should pay greater attention to earlier periods in Middle Eastern history, which help to explain the establishment of indigenous examples of civil society. For Blaydes, it was the emergence from Late Antiquity that developed - and indeed institutionalised - fiscal and bureaucratic capacities that shaped pre-Islamic societies. ${ }^{60}$ This legacy helped the establishment of mechanisms of governance that facilitated economic life. ${ }^{61}$

With this in mind, a number of historians have demonstrated that the Muslim state was shaped through the interaction of the political and religious dynamics of the Middle East, ${ }^{62}$ a position endorsed by Blaydes. ${ }^{63}$ This argument shows how a range of factors and time periods, including the pre-Islamic, Islamic, colonial and postcolonial, shaped contemporary forms of political organisation. ${ }^{64}$ Moreover, norms may be comprised of the residue of previous experience that remains in the historical narratives of the state or the public consciousness. Of course, some incidents had more impact than others. Indeed, the fall of the Ottoman Empire and other colonial experiences had an existential impact upon urban life across the region. ${ }^{65}$

Within this process of (re)construction, reform plays a prominent role in (re)shaping identity. Perhaps the most obvious example of symbolic reform is the treatment of women, wherein both legal and normative structures shape the capacity of women to act in particular ways. In Saudi Arabia, for instance, historically the role of women in the kingdom has been referred to as 'a benign apartheid' and a 'gender apartheid', reflecting the severity of legal, political and religious restrictions placed on women. ${ }^{66}$ The severity of such expectations was felt by all living in the kingdom. One couple who worked in Saudi Arabia during the 1980s told me of a time when they had been at a party in the desert and as the man was inebriated, his female partner had driven them back to the outskirts of Riyadh. Fearing the implications of being caught driving - among a number of other convention-breaking activities - they took the decision for her inebriated partner to drive them home; the risk to their lives was seen as far less than what would happen if she had been caught driving. ${ }^{67}$

Of course, this has broader consequences for both the nature of society but also the construction of identity, as women are often seen as the bearers of particular identities; accepting this premise means that women can also be viewed as responsible for the construction of those identities. ${ }^{68}$ Moreover, fears about the detrimental impact of 
foreign workers led to the systematic exclusion and expulsion of people who were perceived of eroding such values, a practice that continues to this day. ${ }^{69}$

\section{The military and mukhabarat}

In addition to developing (neo)patrimonial systems and reserves of legitimacy, regimes also developed coercive mechanisms to retain power. A prominent part of maintaining power was the cultivation of strong - and often parallel or competing - military and security institutions. Created more for political and symbolic purposes than in response to particular threats, they were designed to maintain power amid widespread uncertainty. In an effort to exert control, security apparatuses facilitate the destruction and reconstruction of social dynamics in support of a regime. With a focus upon both foreign and domestic threats, the establishment of institutions such as the mukhabarat were designed to both facilitate the regulation of life across a state but perhaps more importantly to ensure regime survival. With this in mind, the mukhabarat should be seen as a partisan mechanism of control, designed to regulate life.

Amid a climate of coup proofing during the 1960s and 1970s, security institutions were typically woven into the fabric of the state to facilitate regime survival. Thus, ensuring the loyalty of the security apparatus was a prominent aspect of regime survival strategies. As Eva Bellin astutely suggests, the security establishment is most likely to abandon its project amid serious financial uncertainty. When the military apparatus lacks the ability to maintain the coercive apparatus, it is compromised and disintegrates. ${ }^{70}$ Ensuring the loyalty of military and security institutions was thus of paramount importance. Locating these institutions within (neo)patrimonial structures served two goals: providing the opportunity to reward family members, while also ensuring the loyalty of key institutions of state.

Beyond this, militaries play a prominent role within the cultivation of legitimacy and pride in nationalist projects. From vast military spending to military service, the military as an institution is central within political projects. The relationship between military and state structures has typically been close, with former military leaders becoming political leaders, while politicians across the region have served time in the armed forces as a means of improving their standing and cultivating relations with the institutional power of the state.

Militaries have also played an important role in determining political structures. In Turkey, for example, military figures have served as the self-styled protectors of democracy by maintaining the secular characteristics of the constitution. Of course, the context-specific strength of security apparatus and the prestige with which the military are held can also pose a serious threat to domestic stability, through a capacity to topple regimes. The greater that the security services are institutionalised within the state bureaucracy, the more willing it will be to disengage from politics.

Put another way, if institutionalised, an identity is developed that is separate from the state and a clear career path is opened for officers who, as Eva Bellin suggests, may not be concerned that they will be 'ruined by reform. ${ }^{\text {'1 }}$ Additionally, the military serves 
as a prominent facilitator of the neopatrimonial structures that have characterised regional politics. Institutions are then organised along patrimonial lines, linking members through blood, sect or patronage, blurring the distinction between public and private and linking the interests of military leadership and regime. ${ }^{72}$

Hafez Al Assad's rule in Syria between 1970 and 2000 was one characterised by repression and strong neopatrimonial networks, which built upon both a carefully cultivated cult of personality and a strong Baath ideology. ${ }^{73}$ The military also built upon tribal and familial networks to ensure that people loyal to both regime and leader fill key positions. These employment decisions give key security portfolios to loyal allies, feeding the construction of 'deep states', where security apparatus interests coalesce with both regime and economic interests. As such, portfolios under security apparatus control accrued vast wealth and created a vested interested in maintaining the status quo. ${ }^{74}$

As was common across the region at this time, the upper echelons of military and state bureaucracies were populated by close family members and other groups that benefitted strongly from patronage networks, such as the Alawi community in Syria, who comprised $11 \%$ of the population. ${ }^{75}$ The economic interests of the Alawi community quickly became intertwined with the survival of the Assad regime. ${ }^{76}$ This power was underpinned by a strong coercive infrastructure and an 'absolute presidency', and although elections occurred, these were largely symbolic. ${ }^{77}$ Opposition groups such as the Muslim Brotherhood and other civil society actors were emphatically crushed to solidify such moves, resulting in the deaths of an estimated twenty-five thousand civilians. $^{78}$

Similar experiences were found in Ba'ath Iraq, where Saddam Hussein cultivated a similar cult of personality. ${ }^{79}$ His sons Udai and Ousai controlled key security and economic portfolios, but while Assad relied upon the Alawi community for support, Saddam drew upon the tribes and Tikritis. ${ }^{80}$ The military played an integral role in ensuring this support, yet a sense of paranoia emerging from the spate of regional coups d'etat prompted Saddam to create five overlapping intelligence agencies to watch the military, militias and each other. ${ }^{81}$

One of the most prominent examples of such an institution is the National Guard, a mechanism through which ruling elites historically distributed funds across neopatrimonial networks of tribal and Bedouin leaders. It is an institution of social control through the cultivation of strong alliances but is typically not a force to help deal with internal strife, such as urban disorder, border security or other military missions. In the Jordanian case, the interaction of such factors within the military creates a range of processes that transcend the military, carrying their production 'to the realm of national culture. ${ }^{82}$ In Saudi Arabia, the National Guard - established as successor to Ibn Saud's ikhwan - remain independent of the national military, tasked predominantly with ensuring the survival of the ruling family.

As a consequence of possessing a great deal of political influence and having accrued vast financial resources in the process, it is hardly surprising that militaries have typically been against reform that would reduce their power. Often playing the 'long game', military structures retained power and influence through a delicate balancing of 
political and economic interests and the continuation of (neo)patrimonial structures. Where military and security institutions were negatively affected, much like in Iraq and Yemen, the consequences have been dire as the marginalisation of individuals with military training and access to high-tech weaponry can have negative implications for regime stability.

\section{Legitimacy and neopatrimonialism}

Once constitutions and political structures have been established, political life is regulated in accordance with turath, which serves as a means of excluding individuals from political life. Such structures also facilitate and entrench neopatrimonialism as a tool of regime survival, through the positioning of family and tribal figures in key institutional positions, along with economic incentives. This ensures that a number of authoritarian regimes - those with strong neopatrimonial systems - were able to withstand domestic and regional pressures. ${ }^{83}$ Neopatrimonialism not only involves the distribution of resources as a means of maintaining support, but also the allocation of prominent political positions and portfolios, serving as a means of cultivating loyalty and of circumventing political unrest.

Legitimacy plays an important role, providing some semblance of cover for the lack of democratic input, widening the support base and restricting populist movements. Such strategies are wide-ranging, employing religious, cultural, historical and economic factors. In addition to this, the importance of external influences provides support for regimes through the provision of aid or speeches supporting the regimes in international forums. When exploring neopatrimonialism, a distinction must be made as to the desired reach of such acts: Is the intention to secure the loyalty of prominent figures in key institutional positions, or is it to engender backing from across a larger support base? How one answers this question determines the strategies and narratives involved in political and security responses.

In considering the importance of bureaucratic institutions we must remember the impact of competing visions of nomoi that shape the construction of such institutions. While the importance of religion and Islamic law in shaping institutional development cannot be ignored, ${ }^{84}$ we must also note that the importance of tribal values, which go some way to regulating contemporary life albeit requiring regulation within the context of the contemporary state..$^{85}$ This position is also held by Wael Hallaq, who stresses how political leaders are required to operate within the context that they inherited, which demonstrates a 'cumulative history of past action and specific manners of conduct. ${ }^{86}$

The nature of political organisation prior to the establishment of contemporary states gave prominence to tribal leaders. As such, the need to assimilate tribes into political projects and networks of patronage was of paramount importance. The successful implementation of institutionalised coercive networks creates a particular form of political and economic life that can ensure loyalty to new regimes. Yet the need to restrict the power of the tribe necessitated a delicate balancing act, requiring the limitation of tribal power and influence of particular actors, while retaining the 
normative aspects that facilitate the construction of legitimacy particularly through tribal dress and customs. ${ }^{87}$ The tribe serves as a means of legitimising rule through the provision of normative support for ruling elites while also eroding the coherence of the sovereign state.

\section{The evolution of political life}

Let us now consider the interaction of nomos and nomoi, formal and norm in shaping political life. The following section considers Turkey, Iran and Israel as states where the formal and normative clash to regulate life. These examples provide rich material to consider how religion shapes the interaction of ordnung and ortung and, from it, the construction of citizenship and political structures in contrasting ways. These cases although on the periphery of the region, all hold elections and explicitly articulate the role of religion within the fabric of the state.

In Turkey, after the fall of the Ottoman Empire, political life in the crumbling empire's heartland had collapsed. Under Mustafa Kemal Attatürk, a new state was established at the Treaty of Lausanne in 1923, from the embers of empire, with an explicitly secular vision at its core. ${ }^{88}$ This almost militant form of secularism pushed religious practice to the margins of society, changing the official language from Arabic to Turkish and sought to curtail the public influence of the ulema. This move sought to facilitate rule 'by positivism not superstition, ${ }^{89}$ yet in later years Ottoman traditions and cultures are said to play a more prominent role - albeit in an elusive way - ultimately leading to the emergence of the Justice and Development Party (commonly known as the AK Parti or AKP). ${ }^{90}$

The 'Six Arrows' of Kemalism facilitated widespread transformations across the new state, eroding the legacy of Ottoman rule. ${ }^{11}$ It was this secularist agenda that had the most substantial impact upon Turkish public life and while religion retained influence within the private sphere, it would be removed from the public sphere. ${ }^{92}$ In the following decades, Islamist groups gained influence, yet the secular identity of the Turkish Republic was maintained - and indeed enforced - on a number of occasions by the Turkish military in the face of rising Islamist agendas.

Following the ratification of the 1924 constitution, Article 88 stated that the people of Turkey regardless of their religion and race were, in terms of citizenship, to be Turkish'. A number of problems emerge from this definition, concerning belief, language, national belonging and ideology, although state practice has been different, which had a 'racist-ethnic visage' and a focus upon language. ${ }^{93}$ The Sheikh Said rebellion of 1925 brought such issues to the fore, notably questions about Kurdish integration into the new state. State policies to such questions involved relocation and ethnic redistribution and were supported by grassroots movements such as the Citizen Speak Turkish campaign, resulting in political exclusion..$^{94}$

Turkey provides an obvious example of how normative practices of citizenship, manifesting in exclusion, discrimination, relocation and marginalisation can differ - and have a serious, transformative impact upon people - from formal, legal 
positions. The combination of formal and normative structures helps to solidify regime and broader manifestations of hegemonic identities at the state level, resulting in deeper structural tensions within society. Such tensions then become embedded within the fabric of the state, reproducing themselves over time and manifesting in periods of intermittent violence that, in turn, have implications for the ordering of space.

In contrast to Turkey, religion occupies a more central role in post-revolutionary Iran, as state structures - both formal and normative - shaped life. The revolution in 1979 toppled the authoritarian regime of the Shah, Reza Pahlavi and imposed a new theocratic system of government, veleyat-e faqih, the Regency of the Jurist. This system, a theocracy with democratic traits, locates power in the hands of a supreme leader (Articles 5 and 107), whose position is given as a consequence of their Shi' $i$ credentials. ${ }^{95}$ Political order is conflated with theological aspects to create a system of checks and balances where democratic elements are supervised by the Guardians Council to ensure that everything is run in accordance with Khomeini's ideas. ${ }^{96}$

Khomeini rejected the need for government to create laws, believing that, 'If laws are needed, Islam has established them all. ${ }^{97}$ The Iranian constitution supports this thesis, articulating that Islamic principles and norms exemplified in the revolution 'represent an honest aspiration of the Islamic Umma. ${ }^{98}$ The revolution transformed all aspects of life in Iran. Women's dress also became a site of contestation, as state forces enforced the 'correct' wearing of hijabs. ${ }^{99}$ Although a theocracy, elections are held for the majlis, the office of the president and a number of other bodies within state machinery; presidential candidates are, however, vetted by the Guardians Council.

Iranian identity is certainly not without problems. Although the state draws heavily upon a fusion of Persian nationalism and Shi'a thought, such identities are exclusionary to both ethnic and religious minorities, where around $50 \%$ of the population belong to minority groups. ${ }^{100}$ Iran's nationality law was ratified by the majlis in 1929, where citizenship is 'the indisputable right of every Iranian, ${ }^{101}$ defined initially as someone born to an Iranian father. ${ }^{102}$ From this definition, a number of issues emerge around gender, religion, ethnicity and social origin. A direct consequence of problems with nationality has reduced both Faili Kurds and Khavari Afghans to the status of stateless peoples - essentially homo sacer - many of whom are living in camps and local communities, facing discrimination and restrictions to education, healthcare and employment. ${ }^{103}$ Such tensions also manifest in structural violence over issues of language and cultural practice. ${ }^{104}$

Formal structures within the Iranian political system are designed to protect the vision of veleyat-e faqih but central to the construction of the contemporary Iranian identity is the fusion with Persian nationalism, driven by a history of conquest, expansion and a strong cultural legacy. This combination of formal with normative shapes political action and behaviour, formalising marginalisation and discrimination within the political system and the broader fabric of the state. The combination of state security mechanisms with the basij, the quasi-informal militia responsible for regulating opposition behaviour across the state, demonstrates the all-encompassing nature of veleyat-e faqih across Iran. 
In contrast to both Turkey and Iran, Israel offers a much more conceptually complex discussion of citizenship, with an array of different identity groups operating across the state. The Israeli notion of citizenship is derived from an ethnonationalist discourse, based upon Jewish descent (from the mother) and a fusion of both collectivist republicanism and individualist liberalism. ${ }^{105}$ Amid a number of domestic challenges, particularly related to a relatively small population size, the Law of Return (1950) gives automatic citizenship to any individual with a Jewish grandparent who migrates to Israel, rather than the religious definition of a Jew. As Gershon Shafir and Yoav Peled argue, this law 'became the most important legal expression of Israel's self-definition as a Jewish state. It established ethno-nationalist citizenship that, in principle, encompassed all Jews, and only Jews, by virtue of their ethnic descent?. ${ }^{106}$ This discourse of citizenship was fused with interpretations of the Zionist ideology - itself contested as to its vision of the state and the construction of society - and as a consequence, privileged Orthodox Jews as the 'true keepers' of the faith within Israeli society. ${ }^{107}$

Amid this array of identities Zionist bodies sought to homogenise Israeli society both ethnically and in terms of the urban landscape, as we shall see in Chapter 5. Even with such efforts, divisions within Jewish communities can be identified, creating classes of Jews according to diasporic roots, dividing society into Ashkenazi (European) and Mizrahi (Middle Eastern and North African) who were historically pushed to the periphery of society, although in recent years this marginalisation has been directed against Russian and Ethiopian Jews. The ensuing kulturkampf is predominantly found politically, ethnically and in the religious-secular struggle over political life and the character of the hegemonic narrative within the Israeli state. ${ }^{108}$ Legal structures regulate daily life according to the Torah through observing the Sabbath, the prioritising of religious law over civil courts, state support for religious educational institutions and widespread military exemption for members from the Orthodox communities. ${ }^{109}$ Amid concern at the perceived secularisation of Israeli society and increased prejudice towards Orthodox Jews, a number of Jewish political parties emerged that put faith at the centre of their political agendas.

After the Declaration of the State of Israel in 1948, political culture was built upon a synthesis of religious and secular ideas that were supplemented by Ben Gurion's concept of mamlachtiyut, understood as acting in a sovereign-like manner, concerned with the distribution of power. Supporting this project were the colonial laws of the British mandate that provided legal ground for emergency laws. The new state behaved in a pioneering manner, responding to the ideals of Zionism and expected citizens to contribute towards this broader Zionist project. ${ }^{110}$ Somewhat counter-intuitively, this also applied to those Palestinian-Israelis who became a minority in Israel after the 1948 war and were granted citizenship, albeit with minority status. Through this combination, the nascent Israeli state took shape, yet it retained a fundamental tension between its ethnic and democratic characteristics that can be revealed in a hierarchy of citizenship, which simultaneously differentiates and incorporates. Ideas of citizenship make a distinction between those non-citizens, living under occupation in the West Bank and Gaza, which institutionalised the subjugation of Palestinian populations. 
Such Palestinians thus remain distinct from Palestinian-Israelis living within Israel who are considered to be citizens, albeit with fewer rights.

When one looks at Israeli society, the ethno-nationalist discourse separates Jews from Palestinians, while the republican discourse legitimises and differentiates between the Ashkenazi, Mizrahi and other subjugated groups in Israel. ${ }^{111}$ Such differences became embedded within political institutions and society. Along with this, the dominance of Judaism, as both formal and normative structure, plays a prominent role in the regulation of life across the state, politically and culturally. Formal and normative structures have collapsed into one another, changing the characteristics of the Israeli state, where structural violence along Jewish lines becomes a defining part of relations between Jews and non-Jewish identity groups across both Israel and the Palestinian territories.

\section{From the cradle to the grave and everything in-between}

Such issues are not limited to states with elections. The presence of vast amounts of natural resources facilitated political development in the postcolonial period, resulting in the establishment of 'rentier states', where the extraction of natural resources provides the financial resources to facilitate development, albeit not without democratic repercussions. For Rolf Schwarz, rentier states are understood as those that

derive most or a substantial part of their revenues from the outside world and the functioning of their political system depend to a large degree on accruing external revenues that can be classified as rents. Rentier states rely on allocation and redistribution (allocation states) and hence show a remarkable different political dynamic than other states. ${ }^{112}$

These different dynamics reflect political, cultural, economic and religious values and regime projects are aided by vast financial resources.

Regimes in rentier states enjoy a degree of autonomy from society. The use of natural resources by regimes across the Gulf allowed leaders to create a form of social contract, where citizens paid little or no taxation but have a limited formal political voice. Rentier projects have economies that are typically state driven, with institutions that are designed to reflect local customs ${ }^{113}$ and distributed across networks of patronage. The accumulation of finance through the sale of natural resources to external actors is central to the rentier state, which then allocates and redistributes finances across society. This reduction - or removal - of taxation within political life poses a number of challenges to those wishing to offer a taxonomy of states across the Middle East, while also resulting in a range of serious political consequences.

Vast financial resources create a workforce driven by a set of assumptions about desired job type rather than responding to demand. As a consequence, rentier states are typically home to huge numbers of migrant workers who are often caught within a zone of indistinction and the ban. In many cases, migrant workers are the most visible in public spaces: For tourists visiting the Gulf, the service industry is populated by 
migrant workers, whose rights and legal status are often restricted without recourse to legal and political protection. ${ }^{114}$

Kuwait is typically held to be one of the more democratic states within the Middle East, with a spirit of compromise at the heart of political life. Ruling elites in Kuwait have exploited vast financial resources brought about by rent from oil and gas to reorganise state institutions, maximising symbolism and loyalty, while also providing limited political space for an elected parliament and civil liberties. At this point, loyalty to the land was central to the development in Kuwait although there were no clear borders and territory was contested. Devotion to the land superseded allegiance to the tribe, seen in the battle of Al Jahra, where members of the Al Mutairi tribe were pitted against each other as Saudiled forces went into battle against their neighbours to the east. Defence of the country was seen as tantamount to defence of the ruler and, by extension, protection of the Al Sabah meant the protection of Kuwait. Those who fought in the battle were offered citizenship, while many of those who did not became bidoon, those without the state. ${ }^{115}$

To understand how such conditions have emerged, we must consider political life before the oil boom which reveals a strategy of inclusion, designed to ensure regime survival amid tribal and geopolitical pressures. The severity of such pressures forced the dynastic Al Sabah regime to compromise instead of coercing, unlike most of its neighbours. The Al Sabah brought a range of different groups into the political realm, sacrificing resources to maintain networks of patronage and continue welfare projects $^{116}$ with tribes - who were typically attracted to the military and police ${ }^{117}$ merchant classes, urban workers and even Shi'a groups. In doing this, the Al Sabah embedded its legitimacy - and survival - in the stability of its society, resulting in some viewing the Al Sabah more positively than a number of the other regimes across the region. Another manifestation of such views was seen in the enfranchisement of Kuwaiti women during the 1990s, in spite of resistance from more conservative parts of society and broader regional voices. ${ }^{118}$ Such moves were not purely altruistic, however, as the $\mathrm{Al} \mathrm{Sabah} \mathrm{concentrated} \mathrm{key} \mathrm{ministerial} \mathrm{portfolios} \mathrm{in} \mathrm{the} \mathrm{hands} \mathrm{of} \mathrm{a} \mathrm{small} \mathrm{number}$ of families and maintained a stronghold on the most important six ministries. ${ }^{119}$

Part of this process of inclusion involves engaging with Islamist parties, such as the Muslim Brotherhood, who have fed into constructions of legitimacy. Typically, the socially active side of groups like the Muslim Brotherhood develops legitimacy, but the distribution of oil wealth and provision of welfare - referred to by one US diplomat as 'cradle to the grave and everything in-between'120 - restricted space for groups like the ikhwan, pushing them towards the political sphere. ${ }^{121}$ The constitution protects the freedom of association, although the political climate has restricted the establishment of certain groups at precarious times. Such space allowed for the establishment of a local branch of the Muslim Brotherhood in 1963, which then proved useful to the Kuwaiti state in their effort to balance against the rise of Arab nationalism. Over the coming decades, the Muslim Brotherhood continued to play a prominent role in Kuwaiti politics, facilitating political reform of twenty-five districts to ten, while allying themselves with secular parties as a means to avoid discreditation. ${ }^{122}$

A positive form of political regulation occurs through the distribution of land in Kuwait, establishing cohesion among the family and providing close members with 
access to the business sector. Allocation of land would embed mercantile classes into the burgeoning bureaucratic structures, while instilling Kuwaiti citizens with the belief that one day they too may own land in their country. Similar practices occurred in the UAE, where it was alleged that each citizen would be allocated three plots of land. ${ }^{123}$ Moreover, this also serves to depoliticise domestic communities, leaving the political arena to ruling families as other actors are moved into the economic sector, albeit with loyalty to the state. ${ }^{124}$

A more negative case is found when considering the bidoon jinsiya - stateless people - who have long been marginalised from official state structures. ${ }^{125}$ Kuwait's national identity law defines citizens as those who had settled in the country before 1920 , or who had been naturalised at a later date. Bidoon are those who either refused or were unable to gain Kuwaiti citizenship during the formative years of the state, many of whom are descendants of Bedouin tribes such as the Shammar and 'Aneza. ${ }^{126}$ Fearing instability from the movement of people, the Kuwaiti government sought to strip political life from bidoon and to restrict access to public goods. Marginalised from state structures, they are unable to register for citizenship, access free education in state-run schools, register vehicles or purchase telephone lines and SIM cards. On their driving licences, bidoon are registered as 'illegal residents. ${ }^{127}$ In this case, they are not covered by international law as Kuwait is neither a signatory to the 1954 Convention Relating to the Status of Stateless Persons, nor the 1961 Convention on the Prevention of Statelessness. From this, it appears that the bidoon exist as a prime example of hominus sacri, existing in bare life, without recourse to political and legal structures yet bound by the very structures that abandon them. An Amnesty International report in 2016 estimated that one hundred and twenty thousand people are bidoon in Kuwait. ${ }^{128}$

In neighbouring Bahrain, a system of minority rule - of Sunni over Shi'i historically established a form of sectarian difference into political life, stemming from long-standing fears about the other. ${ }^{129}$ Across the history of twentieth-century Bahrain, Shi'a Bahrainis were relegated to second-class status on the island, along with urban labourers from the Asian subcontinent, as the Sunni regime sought to maintain political control by empowering the Sunni minority. Tracing relations between Shia groups and the regime reveals a number of crisis points: after the Iranian revolution, in the mid-1990s and more recently after the Arab Uprisings. ${ }^{130}$ A number of political and legal structures were established that sought to regulate political life, such as the Law of Political Association Article 4 which prevents the establishment of an organisation based on sectarian, religious or ideological grounds.

In the decades after the British withdrawal, a climate of political dissatisfaction consumed the island where sectarian identity was seen as a threat to political stability. ${ }^{131}$ Although political life is far more complex than the binary delineation of sectarian difference, Shi'a groups have historically been viewed as a source of opposition. ${ }^{132}$ One report for a Bahraini ministry noted:

[T]here is a dangerous challenge facing Bahraini society in the increased role of the Shì a [and] the retreat of the role of the Sunna in the Bahraini political system; namely, the problem concerns the country's [Bahrain's] national security, 
and the likelihood of political regime change in the long term by means of the current relationships between Bahrain's Shì' a and all the Shì'a in Iran, Iraq, Saudi Arabia’s eastern region, and Kuwait. ${ }^{133}$

Much like the history of Iraq, perception of perfidious interference dominated relations between the Al Khalifa regime and its Shi'a population, coloured by beliefs about Iranian interference in domestic affairs. ${ }^{134}$ Such perceptions have had a detrimental impact upon Shi'a politics across the island, as parties such as Al Wefaq have experienced widespread discrimination and their leaders have been jailed. Moreover, a number of Al Wefaq MPs have been arrested and stripped of their nationalities with devastating consequences for themselves and their families. In some cases, family members were detained and tortured, cast into bare life as regimes exert sovereign power in a flagrant attempt to survive whatever the cost. ${ }^{135}$

\section{Creating the ban}

Within the spatialised exception, different manifestations of localised nomos are shaped by particular contingency and subjectivity, restricting political activity and perceived challenges to regime authority and legitimacy in accordance with contextspecific dynamics. In response to such challenges, regimes seek to create exclusion and legitimacy to facilitate, justify and normalise mechanisms of control. One such mechanism is to cultivate a sense of belonging to normative and ideational communities that can then be strengthened and mobilised over time, ${ }^{136}$ fed into neopatrimonial structures and preserved through the distribution of wealth and cultural capital. ${ }^{137}$ Supporting these approaches is the declaration of a state of exception.

For Agamben, the ban emerges as derogation from constitutional clauses is undertaken in order to protect the political project. The onset of much emergency legislation has its roots in colonial times, where the British sought to regulate life and establish order in tumultuous times. Across Israel and Palestine, recourse to British Mandate Law has provided scope for the use of emergency powers, regulating the Arab citizens of Israel between 1948 and 1966, while also regulating life in the West Bank. ${ }^{138}$ Moving responsibility for peace and order from the police to the military was a key strategy and an indispensible means of defending imperial interests. With roots in the 1883 Act for the More Effective Suppression of Local Disturbances and Dangerous Associations, the move allowed for the use of extraordinary powers that had previously been restricted under common law. Further exploration of emergency legislation sees almost routine suspension of the law in times of crisis, reflecting a broad desire to stay in power, albeit facilitated by local context and history. Such laws are primarily used as mechanisms of control, in defiance of Article 4 of the International Bill of Human Rights' prohibition of discrimination.

We should not view political structures as neutral. As we have seen, the interaction of formal and normative structures has an undeniable impact upon the regulation of life, both letting life live and defining the type of life that is acceptable to be lived, with 
the ban a key part of this regulation. The ban emerges not only through potentiality found in democratic systems but also as a consequence of the development of political structures that are inherently exclusionary. Moreover, as Wael Hallaq argues, we can identify five metaphysical 'form properties' that constitute states, which reveal abstract similarities in political organisation that allow us to apply Agamben's case to the Middle East. These include a constitution from historical experience, sovereignty and ensuing metaphysics, legislative monopoly, bureaucratic machinery and a cultural hegemonic engagement with the social order. ${ }^{139}$ Of course, such comments are deeply contested but provide an entry point into discussions of sovereignty and the ban in non-democratic states.

The application of states of emergency varies across the region, from royal decree to two-thirds majority of parliament. In Qatar, Article 69 of Chapter IV states that the Prince [sic] declares emergency law. The article then gives the Prince the power to take

all the prompt measures needed to confront any danger threatening the State's safety, or the integrity of its territory, or its People's security and interests, or obstruct the State's institutions from performing their functions, on condition that the decree must include the nature of the exceptional circumstance for which the Martial Law was declared, and prescribe the measures taken to confront it.

In Jordan, the application of a Defence Law by Royal Decree can establish conditions of martial law, which may also 'impose a limited censorship on newspapers, publications, books and information and communication media in matters related to public safety and national defence purposes'. In Saudi Arabia, the responsibility lies with the King, as enshrined in Article 61 of the Basic Law. Article 62 states that, 'If the King feels that these measures may better be permanent, he then shall take whatever legal action he deems necessary in this regard'. As we shall see in the next chapter, this ability to define the exception - an expression of sovereign power - ultimately raises a number of questions about the source of that power.

Across the region we can group the reasons for derogation from the rule of law and declarations of states of emergency into three areas: war, coups d'état and general unrest. The establishment of the state of Israel was coeval with declaration of emergency legislation in Israel, along with martial law in Iraq in 1948, but the 1967 war created states of emergency in Egypt, Jordan and Syria. It also resulted in similar conditions in Lebanon only five years later. Amid concerns about their role in domestic politics and Israeli activity, Hizballah declared a state of emergency in 2018, asking myriad questions about sovereign power in the process. Following the Iraqi invasion of Kuwait in 1991, the later also declared martial law.

In the decades after the establishment of Israel, the interaction of parabolic pressures created a climate of uncertainty and unrest, resulting in a series of coups d'état across the region. Within this climate, Egypt, Saudi Arabia, Turkey, Syria, Yemen, Jordan, Lebanon and Iraq all derogated from the rule of law to maintain power. Additionally, amid conditions of domestic unrest, Saudi Arabia, Bahrain, Iraq and Egypt all declared emergency laws. Central to such moves were desires to maintain power, regulate space 
and retain territorial integrity amid fear about efforts to alter spatial borders and the regulation of life. In these cases, the state of exception has become the norm, where emergency legislation is taken to be a necessary part of normal politics and individuals reside in camps, both physical and metaphysical. Such a move changes the nature of political life in the region, making the exception the rule and creating the conditions wherein individuals become hominus sacri.

\section{Conclusions}

The space within which ordnung and ortung interact defines both nomos and sovereign power. Understanding the political structures that order space requires consideration of the specific context and contingency. In many cases, this is shaped by both colonial experience and broader understandings of turath and belonging. A range of different identities thus emerge and clash within nomos. Political structures try to regulate the manifestation of such identities and tensions through constitutions, institutions and regulating civil society. Returning to Migdal, regimes seek to regulate and penetrate society, while others seek to stymie such intentions.

While it is clear that biopolitical projects aim to regulate life, this chapter has shown that a spatial dimension surrounds such efforts, wherein norms and multi-layered concepts of identity clash with more formal political structures creating a zone of indistinction between ordnung and ortung. By exploring the political realm we have come to see that it serves as an arena through which layered and complex understandings of identity and citizenship merge and are regulated by norms - often in tension with formal structures - to create a particular type of spatial ordering. Here, much like the tale of Antigone, competing visions of political ordering often clash with one another.

There is little doubt that normative structures play a strong regulatory role, which goes some way to explaining the survival of the Gulf monarchies who are able to draw upon a strong sense of asabiyyah, which creates deep schisms in times of uncertainty. Norms and personal relationships reflect both the importance of tradition but also the instability of formal institutions, serving as a source of opposition. ${ }^{140}$

As Nicolas Gavrielides argues,

What makes tribal ideology even more powerful and pervasive besides being truly Arab, is the fact that it is never formally articulated, stated, written down or even openly criticized. It is just there, permeating every action, thought or process which is of socio-political significance. ${ }^{141}$

Although somewhat hyperbolic and quick to ignore the importance of vast financial might, Gavrielides makes an interesting point about the power of norms in regulating life, particularly when embedded within neopatrimonial structures that facilitate the distribution of wealth in accordance with such values.

In doing this, regimes risk creating political projects that are increasingly organised along ethnic, tribal or communal lines, undermining broader political projects, while 
also deepening divisions between particular groups in a negative consequence of Khaldun's asabiyyah. The spatial repercussions of such a move risk opening up fissures within the relationship between ordnung and ortung, the spatialised nomos, along with the broader organisation of regional politics along the lines of a spatialised exception. While Gulf states offer perhaps the most obvious example of such practices, we should not ignore other political projects, for whom defining the spatialised exception is equally challenging, albeit in a range of different ways.

\section{Notes}

1 Roger Owen, State, Power and Politics in the Making of the Modern Middle East (Oxford: Routledge, 1992), p. 10.

2 Ibid., p. 13.

3 Juan J. Linz, 'An Authoritarian Regime: Spain', in Erik Allardt and Stein Rokkam (ed.), Mass Politics: Studies in Political Sociology (New York: Free Press, 1970), p. 255.

4 See, in particular, the work of Rolf Schwarz, 'The Political Economy of StateFormation in the Arab Middle East: Rentier States, Economic Reform and Democratization', Review of International Political Economy, 15 (2008), 599-621.

5 Ilkay Sunar, 'The Politics of State Interventionism in "Populist" Egypt and Turkey', research paper, Bogazici University, Istanbul (1993), 15-16, 29-31.

6 Hannah Arendt, The Origins of Totalitarianism (New York: Harcourt, 1968).

7 Eva Bellin, 'Coercive Institutions and Coercive Leaders', in Marsh Pripstein Posusney and Michele Penner Angrist (eds), Authoritarianism in the Middle East: Regimes and Resistance (Boulder, CO: Lynne Rienner, 2005), p. 23.

8 Egyptian Organization for Human Rights, 'EOHR Issues Report on Impact of Emergency Law' (IFEX, February 2003), available at www.ifex.org/egypt/2003/02/28/ eohr_issues_report_on_impact_of (accessed 10.10.12).

9 See Simon Mabon and Lucia Ardovini, 'Egypt's Unbreakable Curse: Tracing the State of Exception from Ubarak to Al Sisi', Mediterranean Politics (2019, forthcoming).

10 Adend Lijphart, Democracy in Plural Societies: A Comparative Exploration (New Haven, CT: Yale University Press, 1977).

11 This view emerged from discussions with academic colleagues working on these issues.

12 Holger Albrecht and Oliver Schlumberger, “Waiting for Godot": Regime Change Without Democratization in the Middle East', International Political Science Review, 25:4 (2004), 380.

13 Chibli Mallat, 'On the Specificity of Middle Eastern Constitutionalism', Case Western Reserve Journal of International Law, 38:1 (2006), 17.

14 Quran 42:36, 3:53. enjoining 'politics by consultation' (al-amr shura baynakum).

15 Ibid., p. 29.

16 Sammy Smooha, 'The Model of Ethnic Democracy: Israel as a Jewish and Democratic State', Nations and Nationalism, 8:4 (2002), 475-503.

17 Basic Law of Governance (nazam al-hukm) Royal Order A/90 (01.03.92), available at www.saudiembassy.net (accessed 10.02.18).

18 Abdulaziz H. Al Fahad 'Ornamental Constitutionalism: The Saudi Basic Law of Governance', Yale Journal of International Law, 30 (2005), 275. 
19 Simon Mabon, 'Kingdom in Crisis: Saudi Arabia, Instability and the Arab Spring', Contemporary Security Policy, 33:3 (2012), 530-3.

20 Agamben, Homo Sacer, p. 10.

21 Ibid., p. 10.

22 Michael J. Shapiro, 'National Times and Other Times: Re-Thinking Citizenship', Cultural Studies, 14:1 (2000), 79-98.

23 Saskia Sassen, 'Towards Post-National and Denationalized Citizenship', in E. F. Isin and B. Turner (eds), Handbook of Citizenship Studies (London: Sage, 2002), pp. 227-93.

24 Arendt, Origins of Totalitarianism.

25 Bidoon are those who either refused or were unable to gain Kuwaiti citizenship during the formative years of the state.

26 For a historical discussion of this see Andrew Whitley, 'Minorities and the Stateless in Persian Gulf Politics', Survival, 35:4 (1993), 28-50.

27 Gianluca Paolo Parolin, Citizenship in the Arab World: Kin, Religion and Nation-State (Amsterdam: Amsterdam University Press, 2009); Anh Nga Longva, 'Citizenship in the Gulf States: Conceptualization and Practice', in Nils A. Butenschøn, Uri Daivs and Manuel Hassassian (eds), Citizenship and the State in the Middle East: Approaches and Applications (New York: Syracuse University Press, 2000), pp. 179-200.

28 Parolin, Citizenship in the Arab World, pp. 95-111.

29 Zahra Babar, 'Enduring "Contested" Citizenship in the Gulf Cooperation Council', in Nils A. Butenschon and Roel Meijer (eds), The Middle East in Transition: The Centrality of Citizenship (Cheltenham: Edward Elgar, 2018), p. 118.

30 See Mehran Kamrava, 'The Political Economy of Renterism', in Mehran Kamrava (ed.), The Political Economy of the Persian Gulf (London: Hurst \& Company, 2012), pp. 39-68; Hazem Beblawi, 'The Rentier State in the Arab World', Arab Studies Quarterly, 9:4 (Fall 1987), 383-98; Abdulhadi Khalaf, 'The Politics of Migration', in Abdulhadi Khalaf, Omar Alshahabi and Adam Hanieh (eds), Transit States: Labour, Migration and Citizenship in the Gulf (London: Pluto Press, 2015), pp. 39-56.

31 Jane Kinninmont, 'Citizenship in the Gulf', in Ana Echague (ed.), The Gulf States and the Arab Uprisings (Spain: FRIDE and the Gulf Research Centre, 2013), pp. 51-2.

32 Gwenn Okruhlik and Patrick J. Conge, 'The Politics of Border Disputes: On the Arabian Peninsula', International Journal, 54:2 (1999), 230-48; and Claire Beaugrand, 'Nationality and Migration Control in the Gulf Countries', INAMO, 46 (2006), 10-14.

33 Dina Alqadi, 'The Door That Cannot Be Closed: Bidoon Citizenship in the United Arab Emirates' (Unpublished Dissertation, Duke University, 2015), p. 52.

34 See Bennedict Anderson, Imagined Communities: Reflections on the Origin and Spread of Nationalism (London: Verso, 1983).

35 Interview with Saudi academic, 2017.

36 Interview with female Saudi journalist, 2017.

37 Interview with Yemen analyst, 2018.

38 Interview with Bahraini Shi'a cleric, 2015.

39 Interview with Syrian analyst, 2017.

40 Theodor Hanf, Co-Existence in Wartime Lebanon: Death of a State and Birth of a Nation (London: I. B. Tauris, 1993); Antoine Messarra, Théorie Générale du Système Politique Libanais (Paris: Paris-Cariscript, Beyrouth-Librairie Orientale (avec le concours du Centre National des Lettres, 2004).

41 Interview with Lebanese policy analyst, 2017.

42 Ibrahim Nawar, 'Untying the Knot' (Al-Ahram Weekly, No. 625, February 2003), available at http://weekly.ahram.org.eg/archive/2003/625/sc5.htm (accessed 10.10.12). 
43 Toby Dodge, 'Iraq and Muhasasa Ta'ifa; The External Imposition of Sectarian Politics', in Simon Mabon (ed.), Saudi Arabia and Iran: The Struggle to Shape the Middle East (London: Foreign Policy Centre, 2018), pp. 13-14.

44 Interview with Bahraini Shi'a cleric, 2018.

45 Interview with Iraqi Kurdish policy advisor, 2017.

46 For an in depth discussion of this see Khoury and Kostiner, Tribes and State Formation in the Middle East.

47 Khoury and Kostiner, Tribes and State Formation in the Middle East.

48 Ernest Gellner, 'Tribalism and the State in the Middle East', in Khoury and Kostiner, Tribes and State Formation in the Middle East, p. 122.

49 Ghassan Salame (ed.), The Foundations of the Arab State (Oxford: Routledge, 1987), pp. 159-61.

50 John G. Taylor, From Modernization to Modes of production: A Critique of the Sociologies of Development and Underdevelopment (London: Macmillan), 1979, p. 182.

51 Hamid A. Rabi, Suluk al-malik fi tadbir al-mamalik: ta'lif al-allamma shihab al-Din ibn Abi al-Rubayyi' [Suluk al-malik fi tadbir al-mammalik: By the Scholar Shihab al-Din ibn Abi al-Rubayyi'], Vol. 1 (Cairo: Dar al-Sha'b, 1980), p. 218.

52 For example, see Frank H. Stewart, 'Customary Law Among the Bedouin of the Middle East and North Africa', in Dawn Chatty (ed.), Nomadic Societies in the Middle East and North Africa: Entering the 21st Century (Leiden: Brill, 2006), pp. 239-41.

53 Ayubi, Overstating the Arab State, p. 32.

54 Harry Eckstein, Regarding Politics: Essays on Political Theory, Stability and Change (Berkeley: University of California Press, 1991), p. 188.

55 Luciani, The Arab State, p. 78.

56 Ayubi, Overstating the Arab State, p. 125.

57 Bassam Tibi, 'The Simultaneity of the Unsimultaneous: Old Tribes and Imposed Nation-States in the Modern Middle East', in Khoury and Kostiner, Tribes and State Formation in the Middle East, pp. 127-52.

58 Ghassan Salame, Al Mujtama' wa al-Dawla fi al-Mashriq al'Arabi [Society and State in the Arab Levant] (Beirut: CAUS, 1987), pp. 23-4. Salame offers the example of the Alawi of Syria as an example of this.

59 Ayubi, Overstating the Arab State, p. 86.

60 Lisa Blaydes, 'State Building in the Middle East', Annual Review of Political Science, 20 (2017), 487-504.

61 Hugh Kennedy, 'The City and the Nomad', in Robert Irwin (ed.), The New Cambridge History of Islam (Cambridge, UK: Cambridge University Press, 2010), p. 283.

62 C. F. Robinson, 'Introduction', in C. F. Robinson (ed.), New Cambridge History of Islam. Vol. 1: The Formation of the Islamic World, Sixth to Eleventh Centuries (Cambridge, UK: Cambridge University Press, 2010), pp. 1-16.

63 Blaydes, 'State Building in the Middle East'.

64 This is discussed in more detail in the following chapter.

65 Khoury and Kostiner, Tribes and State Formation in the Middle East, p. 122; Salame, Foundations of the Arab State, p. 23.

66 Madawi Al Rasheed, A Most Masculine State: Gender, Politics and Religion in Saudi Arabia (Cambridge, UK: Cambridge University Press, 2013).

67 Interview with British expats based in Saudi Arabia in the 1980s, 2017. Their time there was spent working for a number of different companies who were supported and protected by particular royals. 
68 Al Rasheed, A Most Masculine State.

69 Interview with British ex-pat based in Saudi Arabia in the 1980s, 2017.

70 Bellin, 'Coercive Institutions and Coercive Leaders', p. 27.

71 Ibid, p. 29.

72 Bellin, 'Reconsidering the Robustness of Authoritarianism in the Middle East', p. 133.

73 Lisa Weeden, Ambiguities of Domination: Politics, Rhetoric and Symbols in Contemporary Syria (Chicago: Chicago University Press, 1999).

74 See, for instance, the work of Jean-Pierre Filiu, From Deep State to Islamic State (London: Hurst, 2015).

75 Hanna Batatu, 'Syria’s Muslim Brethren', Middle East Research and Information Project Reports, 110 (1982), 20.

76 Gerard Michaud, 'The Importance of Bodyguards', Middle East Research and Information Project Reports, 110 (1982), 30.

77 Volker Perthes, The Political Economy of Syria under Asad (London: I. B. Tauris, 1995), p. 139.

78 See Alasdair Drysdale, 'The Assad Regime and its Troubles', Middle East Research and Information Project Reports, 110 (1982), 3-11; Fred Lawson, 'Social Bases of the Hamah Revolt', Middle East Research and Information Project Reports, 110 (1982), 24-28; Patrick Seale, Asad: The Struggle for the Middle East (Berkeley: University of California Press, 1988).

79 Kanan Makiya, Cruelty and Silence: War, Tyranny, Uprising, and the Arab World (New York: Norton, 1993), p. 63.

80 Batatu, The Old Social Classes, p. 1084.

81 Isam Al Khafaji, 'State Terror and the Degradation of Politics', Middle East Report, 176 (1992), 19.

82 Joseph A. Massad, Colonial Effects: The Making of National Identity in Jordan (New York: Columbia University Press, 2001), p. 5.

83 Jason Brownlee, '... And Yet They Persist: Explaining Survival and Transition in Neopatrimonial Regimes', Studies in Comparative International Development, 37:3 (2002), 35-63.

84 Blaydes, 'State Building in the Middle East'.

85 P. Crone, 'The Tribe and the State', in J. A. Hall (ed.), States in History (Oxford: Basil Blackwood, 1986), pp. 48-77; I. M. Lapidus, A History of Islamic Societies (New York: Cambridge University Press, 2014).

86 Wael Hallaq, 'Islamic Law: History and Transformation', in R. Irwin, New Cambridge History of Islam. Vol. 4: Islamic Cultures and Societies to the End of the Eighteenth Century (Cambridge, UK: Cambridge University Press, 2010), pp. 152-3.

87 Mabon, 'Kingdom in Crisis'.

88 Andrew Mango, Ataturk (London: John Murray, 1999).

89 Halil Inalcik, 'Learning the Medrese, and the Ulemas', in Halil Inalcik, Ottoman Empire: The Classical Age 1300-1600 (New York: Praeger, 1973), p. 171.

90 Interview with Turkish academic, 2017.

91 The sultan had been kept on to facilitate the smooth transition from New Turks rule to the Turkish Republic.

92 Interview with Turkish academic, 2017.

93 Kemal Kirisci, 'Disaggregating Turkish Citizenship and Immigration Practices', Middle Eastern Studies, 36:3 (2000), 2. See also A. Aktar, 'Cumhuriyetin Ilk Yillarinda Uygulanan Turklestirme Politikalarin', Tarih ve Toplum, 156 (1996), 4-18. 
94 D. McDowall, A Modern History of the Kurds (London: I. B. Tauris, 1996), pp. 184-211.

95 Shaul Bakhash, The Reign of the Ayatollahs: Iran and the Islamic Revolution (New York: Basic Books, 1990).

96 For many Shi'a clerics, these ideas go against conventional Shi'a views, for whom 'the order of the clerical hierarchy is its disorder'.

97 Ayatollah Ruhollah Khomeini, 'Islamic Government', in Hamid Algar (trans.), Islam and Revolution: Writings and Declarations of Imam Khomeini (Berkeley, CA: Mizan, 1981), pp. 137-8.

98 Iranian Constitution, available at www.constituteproject.org/constitution/Iran_1989. pdf?lang=en (accessed 10.02.08).

99 For many Iranian women, pushing the hijab towards the back of the head and revealing hair is an act of what James C. Scott has termed 'everyday resistance'. James C. Scott, Weapons of the Weak: Everyday Forms of Peasant Resistance (New Haven, CT: Yale University Press, 1985).

100 Alam Saleh, Ethnic Identity and the State in Iran (New York: Palgrave Macmillan, 2013).

101 Iranian Nationality Law Article 41.

102 Iranian Nationality Law Article 976 (2).

103 E. Campbell, The Faili Kurds of Iraq: Thirty Years Without Nationality (Refugees International, 2010), https://reliefweb.int/report/iraq/faili-kurds-iraq-thirty-yearswithout-nationality (accessed 10.05.11); and A. Whitley, 'Minorities and the Stateless in Persian Gulf Politics', Survival: Global Politics and Strategy, 35:4 (1993), 28-50.

104 Iranian newspapers routinely feature cartoons that depict members of ethnic minorities as inferior.

105 Yoav Peled, 'Ethnic Democracy and the Legal Construction of Citizenship: Arab Citizens of the Jewish State', American Political Science Review, 86 (1992), 432-43.

106 Gershon Shafir and Yoav Peled, 'Citizenship and Stratification in an Ethnic Democracy', Ethnic and Racial Studies, 21:3 (1998), 412-13. It also became a source of contestation.

107 Yonathan Shapiro, Politicians as a Hegemonic Class: The Case of Israel (Tel Aviv: Sifriat Poalim, 1996), pp. 46-9.

108 Gideon Katz, 'The Israeli Kulturkampf', Israeli Affairs, 14:2 (2008), 237-54.

109 Shafir and Peled, 'Citizenship and Stratification', p. 413.

110 Peled, 'Ethnic Democracy'.

111 Shafir and Peled, 'Citizenship and Stratification'.

112 Rolf Schwarz, 'The Political Economy of State-Formation in the Arab Middle East: Rentier States, Economic Reform, and Democratization', Review of International Political Economy, 15:4 (2008), 604.

113 Alexander Bligh, 'The Saudi Religious Elite (ulama) as Participant in the Political System of the Kingdom', International Journal of Middle East Studies, 17:1 (1985), 37-50.

114 Ahmed Kanna, 'A Politics of Non-Recognition? Biopolitics of Arab Gulf Worker Protests in the Year of Uprisings', Interface: A Journal For and About Social Movements, 4:1 (2012), 146-64.

115 Interview with Kuwaiti academic, 2017.

116 K. H. Al Naqib, Al-mujtama' wa al-dawlah fi al-khalij wa al-jazeerah al-arabiyah [Society and the State in the Gulf and the Arabian Peninsular] (Beirut: Markaz Dirasat al-Wahdan al-Arabiyah, 1987). 
117 I. Al Taher, Kuwait: The Reality (Pittsburg, PA: Dorrance Publishing, 1995), pp. 172-4.

118 Sean L. Yom, 'Oil, Coalitions, and Regime Durability: The Origins and Persistence of Popular Rentierism in Kuwait', Studies in Comparative International Development, 46 (2011), 217-41.

119 Ayubi, Overstating the Arab State, p. 251.

120 'From Cradle-to-Grave: An Overview of Kuwait's Welfare Ban' (Scoop, WikiLeaks, 01.05.06), available at www.scoop.co.nz/stories/WL0605/S01599/cablegate-fromcradle-to-grave-an-overview-of-kuwaits-welfare.htm (accessed 30.07.19).

121 Courtney Freer, 'Exclusion-Moderation in the Gulf Context: Tracing the Development of Pragmatic Islamism in Kuwait', Middle East Studies, 54:1 (2017), 1-21.

122 P. Salem, 'Kuwait: Politics in a Participatory Emirate', Carnegie Papers, 3 (2007), 6. See also Freer, 'Exclusion-Moderation'.

123 Ayubi, Overstating the Arab State, p. 229.

124 Jill Chrystal, Oil and Politics in the Gulf: Rulers and Merchants in Kuwait and Qatar (Cambridge, UK: Cambridge University Press, 1990), p. 109.

125 Typically shortened to bidoon, meaning 'without'.

126 Interview with Kuwaiti academic, 2017.

127 Maureen Lynch and Patrick Barbieri, 'Kuwait: State of Exclusion' (Refugees International, 2007), available at www.refworld.org/pdfid/47a6ee9bd.pdf (accessed 17.05.17).

128 www.amnesty.org/download/Documents/MDE1741452016ENGLISH.PDF (accessed 17.05.17).

129 A prominent theme that emerged in conversation with Bahrainis from different sections of society.

130 C. Kurzman, The Unthinkable Revolution in Iran (Cambridge, MA: Harvard University Press, 2004), pp. 154-62.

131 Frederic Wehrey, 'Bahrain's Decade of Discontent', Journal of Democracy, 24:3 (2013), 118.

132 'Simmering Unrest in Bahrain' (Guardian, 17.04.08), available at www.theguardian. com/world/us-embassy-cables-documents/150213 (accessed 07.05.12).

133 Salah Al Bandar, 'Al-bah rayn: al-khiyār al-dīmūqrātī wa āliyāt al-iqs a', unpublished report prepared by the Gulf Center for Democratic Development (September 2006), cited in Justin Gengler, 'Royal Factionalism, the Khawalid, and the Securitization of 'the Shi'a Problem' in Bahrain', Journal of Arabian Studies, 3:1 (2013), 53-79.

134 Fawaz bin Mohammad Al Khalifa, 'The Gulf States Are Stuck Between Isil and Iran' (Telegraph, 21.01.16), available at www.telegraph.co.uk/news/worldnews/middleeast/ bahrain/12113355/The-Gulf-states-are-stuck-between-Isil-and-Iran.html (accessed 21.01.16).

135 Interview with former Bahraini MP, 2015.

136 Interview with Bahraini Shi'a cleric, 2018.

137 Interview with Turkish journalist, 2017.

138 Israel has no written constitution but has existed under a state of emergency since its inception. After forty years, the Knesset passed the Basic Law of 1992, which provided greater legislative oversight. Within this Basic Law, Regulation 111 allows for administrative detention of up to six months without trial, after which the case must be reviewed by a military advisory committee but detention can be renewed. 
Regulation 125 empowers military commanders to define areas as 'closed', requiring military approval to enter or leave. The regulation has also been used to exclude landowners from their land.

139 Hallaq, The Impossible State, p. 23.

140 Lisa Anderson, 'Absolutism and the Resilience of Monarchy in the Middle East', Political Science Quarterly, 106 (1991), 12-13.

141 Nicolas Gavrielides, 'Tribal Democracy: the Anatomy of Parliamentary Elections in Kuwait', in Linda Layne (ed.), Elections in the Middle East; Implications of Recent Trends (Boulder, CO: Westview Press, 1987), p. 182. 